УДК 618.14-006.327-085

І.Р. Ніцович, О.А. Андрісць, А.В. Семеняк

\title{
ЛІКУВАННЯ МАЛИХ ФОРМ ЛЕЙОМІОМИ МАТКИ
}

Вищий державний навчальний заклад України «Буковинський державний медичний університет», м. Чернівці

Резюме. У статті розглянуто проблему профілактики прогресування росту малих форм міом матки. Відзначена ефективність лікування малих форм міом матки шляхом застосування рослинного негормонального препарату Епігалін. Встановлено зменшення роз- мірів міоматозних вузлів у $16,7 \%$ упродовж шести місяців застосування препарату та нормалізацію менструальних кровотеч у $83,3 \%$.

Ключові слова: лейоміома, індол-3-карбінол.

що матка в організмі жінки відіграє важливу роль не тільки як репродуктивний орган, але і як орган ендокринної системи [1].

Видалення матки $є$ серйозним фізичним порушенням для жіночого організму, спричинює психологічні порушення, призводить до зростання ризику розвитку раку молочної залози, ішемічної хвороби серця, тому пошук консервативних методів лікування набуває актуальності [6].

Відсутність матки спричиняє зниження гормональної активності яєчників і потребує, у деяких випадках, тривалої медикаментозної корекції. Крім того, оперативне втручання супроводжується ризиком ускладнень, які можуть бути значно небезпечнішими, ніж сама міома матки, i тому більшість жінок відмовляються від гістеректомії $[2,4,5]$.

Міоми малих розмірів (міоматозні вузли до 15 мм) не мають клінічної симптоматики та виявляються лише при ультразвуковому дослідженні (УЗД). Однак для субмукозного вузла безсимптомного розміру не існує, оскільки вузол будьякого розміру зумовлює клінічні прояви. Субсерозний вузол, який у два рази перевищує розмір самої матки, може зовсім не давати клінічної картини $[3,5,6$,$] .$

3 патогенетичної точки зору, міома матки малих розмірів може перебувати під впливом фізіологічних рівнів гормонів, тому можливим $\epsilon$ застосування негормональних препаратів $[1,6]$. У цьому разі, за допомогою тривалого консервативного лікування, можна сприяти відсутності їх подальшого росту.

Враховуючи складну систему ендокринних взаємовідносин в організмі, при вирішенні питання про можливість консервативного лікування міоми кращим $є$ застосування таких речовин та препаратів, які володіють м'яким корегувальним i стабілізувальним ефектом. У даний час $є$ можливість використання негормональної терапії міоми матки, застосування традиційних гормональних препаратів має побічні ефекти, не завжди результативне, оскільки причини розвитку пов'язані не тільки з гормональним фактором.

Мета дослідження. Визначити вплив на ріст міом матки малих розмірів негормональних препаратів для профілактики їх подальшого росту.

Матеріал і методи. Проведено клінічнолабораторне обстеження 60 жінок із наявністю матки більшості лікарів, які не беруть до уваги,

(C) І.Р. Ніцович, О.А. Андрієць, А.В. Семеняк, 2016 
міоми матки малих розмірів (основна група), які були розподілені на дві підгрупи: I підгрупа - 30 жінок, яким призначалося запропоноване лікування впродовж шести місяців, II підгрупа (порівняння) - 30 жінок, які відмовилися від запропонованого лікування, та 20 здорових жінок, що становили контрольну групу, патології жіночої статевої системи у них не виявлено.

Матеріалом для дослідження була сировотка крові. Методи дослідження імуноферментний, ультразвуковий, статистичний.

Результати дослідження та їх обговорення. Перед призначенням курсу лікування нами проведено визначення гормонального фону (естрадіол, прогестерон) та ультразвукове обстеження жінок основної групи та контрольної групи.

Гормони яєчника (естрадіол та прогестерон) визначали на 7-й та 21-й день менструального циклу. Для оцінки та аналізу рівня естрадіолу та прогестерону у пацієнток із міомою матки малих розмірів, отримані результати порівнювали 3 результатами аналогічних показників у контрольній групі. На 7-й день менструального циклу концентрація естрадіолу становила: у жінок основної групи - 0,436 $\pm 0,07$ нмоль/л, контрольної групи $0,351 \pm 0,03$ нмоль/л $(\mathrm{p}=0,05)$. Отже, встановлено збільшення рівня естрогенів у жінок основної групи, однак вірогідної різниці не виявлено. На 21-й день менструального циклу вірогідної різниці в кількості естрадіолу також не виявлено. Не виявлено вірогідної різниці при визначенні рівня прогестерону на 7-й та 21-й день менструального циклу.

При аналізі результатів ультразвукового обстеження внутрішніх статевих органів жінок основної групи встановлено наявність субсерозних, інтрамуральних, субмукозних вузлів, не більше 2см у діаметрі, що не вимагають, за показаннями, оперативного лікування. В 11 (36,7 \%) жінок I підгрупи були субмукозні вузли, що клінічно проявлялися гіперполіменореєю, у 9 (30 \%) - інтрамуральні вузли, що також провокували наявність надмірних маткових кровотеч, у 10 (33,3\%) - субсерозні вузли, які у восьми жінок не проявлялися будь-якими клінічними симптомами, у 2 були дизуричні розлади. У жінок II підгрупи розташування міоматозних вузлів вірогідно не відрізнялося від аналогічних у I підгрупі: у 9 (30 \%) жінок - субмукозні вузли з проявами гіперполіменореї, у 10 (33,3 \%) - інтрамуральні вузли, 3 проявами гіперполіменореї, в 11 (36,7 \%) - субсерозні вузли без клінічних проявів. У жінок контрольної групи патологічних змін з боку матки не виявлено.

Після обстеження жінкам I підгрупи призначено лікування препаратом Епігалін по 1 капсулі 2 рази на день під час їжі впродовж шести місяців. Жінки другої підгрупи застосовували симптоматичну терапію.

Епігалін $є$ рослинним негормональним препаратом, який нормалізує в організмі жінок метаболічні процеси, обмін статевих гормонів (естрогенів), володіє комплексним впливом на організм людини, що проявляється в гальмуванні патологічних гіперпластичних процесів в гормон-залежних органах і тканинах жіночої репродуктивної системи, пригнічує патологічний ріст i мітоз клітин в органах і тканинах, зменшує розвиток папіломатозу та ступінь дисплазії шийки матки, викликаних вірусом папіломи людини (ВПЛ). Одна капсула препарату Епігалін містить активні інгредієнти: індол-3-карбінол - 200 мг, епігалокатехін-3-галат- 45 мг.

Індол-3-карбінол $є$ біологічно активною речовиною екстракту сімейства хрестоцвітих (капусти броколі), блокує гормон-залежні та гормон-незалежні механізми, що активують патологічний ріст клітин у тканинах матки. За рахунок посилення активності ферментів системи цитохрому Р-450 нормалізує баланс естрогенів, пригнічує утворення проканцерогенного 16- $\alpha$ гідроксіестрону та сприяє зсуву співвідношення метаболітів жіночих статевих гормонів - естрогенів на користь утворення 2-С-гідроестрону; запобігає проліферації клітин в естроген-залежних тканинах; індукує процеси апоптозу в патологічно змінених клітинах; нейтралізує дію ростових факторів, які стимулюють розвиток пухлин у гормон-залежних органах репродуктивної системи; володіє потужним противірусним ефектом відносно папілома вірусу.

Епігалокатехін-3-галат $\epsilon$ біологічно активною речовиною екстракту зеленого чаю, активує фагоцитоз, стимулює завершеність фагоцитозу, збільшує число фагоцитувальних клітин, має виражену ангіостатичну дію, сприяє зменшенню росту новоутворень; пригнічує інвазивну активність клітин ендометрія; гальмує ріст судин у міоматозних вузлах.

Через шість місяців прийому препарату проведено контрольне обстеження жінок основної групи. Встановлено, що в жінок основної групи спостерігалося зниження концентрації естрадіолу (0,398 00,05 нмоль/л) при визначенні на 7-й день менструального циклу, рівень гормонів на 21-й день менструального циклу вірогідно не відрізнявся порівняно з контрольною групою.

При УЗД жінок основної групи I підгрупи виявлено, що в 5 (16,7 \%) осіб спостерігалося зменшення розмірів вузлів, у решти 25 (83,3\%) розміри вузлів не змінилися, однак пацієнтки відмічали зменшення інтенсивності та тривалості менструальних кровотеч. У жінок основної групи II підгрупи, які відмовилися від лікування, позитивної динаміки не було. У дев'яти 3 них (30\%) спостерігався ріст вузлів.

\section{Висновки}

1. Застосування негормонального препарату зі складом індол-3-карбінолу та епігалокатехіну3-галату в терапії міоми матки малих розмірів, 3 метою профілактики росту міоматозного вузла, призводить до зменшення міоматозних вузлів у 16,7 \%, нормалізації менструального циклу у 83,3 
\%, тому може бути альтернативою в консервативному лікуванні міоми матки.

2. Відмічено вплив лікування на гормональний фон жінок із міомою матки, що проявлялося зменшенням кількості естрадіолу, що забезпечує зменшення інтенсивності клінічних проявів та росту пухлини.

Перспективи подальших досліджень. Визначити динамічні зміни міоми матки малих розмірів при тривалості лікування до одного року.

\section{Література}

1. Астахов В.М. Применение парафармакологического препарата Индол-Ф в профилактике и терапии миомы матки / В.М. Астахов // Таврич. мед.-биол. вестник. 2011. - № 3. - C. 13-16.

2. Вдовиченко Ю.П. Оптимізація лікування хворих міомою матки / Ю.П. Вдовиченко, М.Л. Кузьоменська //
Вісн. Сум. держ. ун-ту. Серія «Медицина». - 2011. № 1. - C. 128-134.

3. Вовк І.Б. Нові підходи до відновлення репродуктивної функції у жінок з лейоміомою матки / І.Б. Вовк, А.Г. Корнацька, В.К. Кондратюк // Здоров'я України. - 2009. - № 24/1. - С. 24.

4. Некоторые механизмы активации пролиферативных процессов в органах репродуктивной системы / Н.С. Луценко, Л.Р. Гераскина, И.А. Евтерева [и др. ] // Мед.-соц. пробл. сім’ї. - 2009. - Т. 14, № 4. C. $134-139$.

5. Стрижаков А.Н. Миома матки: патогенез, диагностика, лечение / А.Н. Стрижаков, А.И. Давыдов, В.А. Лебедев // Вопр. гинекол., акуш. и перинатол. - 2008. № 7. - C. 7-18.

6. Татарчук Т.Ф. Анатомо-функціональні особливості різних клініко-патогенетичних варіантів лейоміоми матки / Т.Ф. Татарчук, Н.В. Косей, Т.Д. Задорожна // Здоровье женщины. - 2009. - № 5 (41). - С. 120-127.

\section{КОНСЕРВАТИВНАЯ ТЕРАПИЯ МИОМЫ МАТКИ}

\section{И.Р. Ницович, О.А. Андриец, А.В. Семеняк}

Резюме. В статье рассмотрена проблема профилактики прогрессирования роста малых форм миом матки. Отмечена эффективность лечения малых форм миом матки путем применения растительного негормонального препарата Епигалин. Установлено уменьшение размеров миоматозных узлов в 16,7 \% в течение шести месяцев применения препарата и нормализацию менструальных кровотечений в 83,3\%.

Ключевые слова: лейомиома, индол-3-карбинол.

\section{CONSERVATIVE TREATMENT OF UTERINE LEIOMYOMA}

\section{I.R. Nitsovych, O.A. Andriyets', A.V. Semenyak}

Abstract. The paper deals with the problem of prevention of the progression of the growth of small forms of uterine fibroids. The effectiveness of the treatment of uterine fibroids small forms through the use of plant non-hormonal drug Epihalin was noticed. We found a reduce in the size of myoma nodes in $16,7 \%$ within six months of using the preparation and normalization of menstrual bleeding in $83,3 \%$.

Key words: leiomyoma, indole-3-carbinol.

Higher State Educational Institution of Ukraine “Bukovinian State Medical University “(Chernivtsi)

Рецензент - проф. О.М. Юзько

(C) І.Р. Ніцович, О.А. Андрієць, А.В. Семеняк, 2016
Buk. Med. Herald. - 2016. - Vol. 20, № 2 (78). - P. 105-107

Надійшла до редакції 16.02.2016 року 